\title{
Maxillary Fibrous Dysplasia with Cone Beam Computed Tomography Findings: A Case Report
}

\author{
Konik Işınlı Bilgisayarlı Tomografi Bulguları Olan Maksiller Fibröz \\ Displazi: Bir Olgu Sunumu \\ (1) Gülsün Akay ${ }^{1}$, (1) Kahraman Güngör ${ }^{2}$
}

${ }^{1}$ Tepebaşı Oral and Tooth Health Training and Research Hospital, Clinic of Oral and Dentomaxillofacial Radiology, Ankara, Turkey

${ }^{2}$ Gazi University Faculty of Dentistry, Department of Oral and Dentomaxillofacial Radiology, Ankara, Turkey

Keywords

Fibrous dysplasia, cone beam computed tomography, ground glass, panoramic radiography

Anahtar Kelimeler

Fibröz displazi, konik ışınlı bilgisayarlı tomografi, buzlu cam, panoramik radyografi

Received/Geliş Tarihi : 05.06.2017

Accepted/Kabul Tarihi : 22.06.2017

doi:10.4274/meandros.86580

Address for Correspondence/Yazışma Adresi: Gülsün Akay MD, Tepebaşı Oral and Tooth Health Training and Research Hospital, Clinic of Oral and Dentomaxillofacial Radiology, Ankara, Turkey

Phone : +90 5359813986

E-mail : akay.gulsun@hotmail.com

ORCID ID: orcid.org/0000-0002-1767-1383

(C) Meandros Medical and Dental Journal, Published by Galenos Publishing House.

This is article distributed under the terms of the Creative Commons Attribution NonCommercial 4.0

International Licence (CC BY-NC 4.0).

\begin{abstract}
Fibrous dysplasia (FD) is a slowly growing benign skeletal fibro-osseous condition, resulting from a localized change in normal bone metabolism that results in the replacement of all the components of cancellous bone by fibrous tissue. A 50-yr-old male patient with FD attended our clinic with a complaint of swelling in the right maxilla. In extra-oral examination, a significant asymmetry was observed. Intraoral examination revealed a painless swelling at the right maxillary posterior region. Increase in bone formation within the lesion was observed with a radiographic appearance that is referred to as "ground glass". The aim of this case report was to present clinical, histopathological and radiographic findings of a patient with FD.
\end{abstract}

Öz

Fibröz displazi (FD) kemiğin iyi huylu yavaş gelişen bir fibro-osseöz lezyonudur. Normal kemik metabolizmasındaki değişimin sonucu kansellöz kemiğin tüm içeriğinin fibröz dokuyla yer değiştirmesi sonucu gelişir. Elli yaşındaki erkek hasta sağ maksilladaki ağrısız şişlik yakınması ile kliniğimize başvurdu. Ekstraoral muayenede asimetri gözlenen hastanın intraoral muayenesinde sağ maksilla posterior bölgede ağrısız bir şişlik belirlendi. Kemik yapımındaki artış ile birlikte "buzlu cam" olarak adlandırılan radyografik görüntü gözlendi. Bu olgu sunumunun amacı FD tanısı konulan bir hastanın klinik, histopatolojik ve radyografik bulgularını sunmaktır.

\section{Introduction}

Fibrous dysplasia is a benign, fibro-osseous lesion of the bone that results from a localized change in normal bone metabolism. This disease usually exhibits as an asymptomatic, slow enlargement of the affected bone (1). The etiology of the disease is still unclear, but several factors play role. The molecular etiology has been linked with a mutation in the Gs- $\alpha$ gene, affecting proliferation and differentiation of fibroblasts/osteoblasts, which is coded by the GNAS1 gene (guanine nucleotide-binding protein, a stimulating activity polypeptide) (1-3). 
Fibrous dysplasia may affect a single bone or multiple bones (4). The most common bones of fibrous dysplasia are the ribs, femur, tibia, maxilla and mandible (5). The mainly forms of fibrous dysplasia are monostotic form (70-80\% of cases) with one bone involvement and polyostotic form with several bones involvement $(6,7)$. Polyostotic fibrous dysplasia may be associated with Mc-Cune Albright syndrome and JaffeLichtenstein syndrome. Mc-Cune Albright syndrome includes polyostotic fibrous dysplasia, multiple endocrine disorder such as precocious puberty or hyperthyroidism and cafe'-au-lait pigmentation on the skin. Jaffe-Lichtenstein syndrome is characterized by multiple bone lesions involvement of fibrous dysplasia and irregular skin pigmentations (café-au-lait spots) $(1,2)$. Mazabraud syndrome is another rare disorder associated with polyostotic fibrous dysplasia, in which fibrous dysplasia is combined with intramuscular myxomas (2). Craniofacial fibrous dysplasia is a form of fibrous dysplasia affecting the cranial base, involves two or more bones of the maxillofacial region and often includes the maxilla, zygoma, sphenoid, temporal bone, fronto-nasal bones and base of the skull $(8,9)$. The monostotic form is usually diagnosed after puberty, patients in the second-third decades can also be asymptomatic, whereas polyostotic form is usually diagnosed before puberty. The monostotic form affects both genders equally, but female predilection has been reported in the polyostotic form $(9,10)$. The aim of this reported is to evaluate clinical, histopathological and radiographic findings of a patient with monostotic fibrous dysplasia.

\section{Case Report}

A 50-yr-old Caucasian man patient was referred to oral and dentomaxillofacial radiology clinic with a chief complaint of unilateral painless swelling of the right maxillary posterior region. It was learned that tooth extraction done years ago because of dental caries. He stated that swelling had occurred in the same area 8 or 10 years ago and had been removed by surgical approach. His medical history was unremarkable, and the neurological examination was normal. In clinical examination, swelling was observed at the right maxillary posterior region and lesion caused painless palatine-vestibule expansion (Figure 1). The overlying mucosa was in normal appearance. In panoramic radiographic examination, partially edentulous maxilla

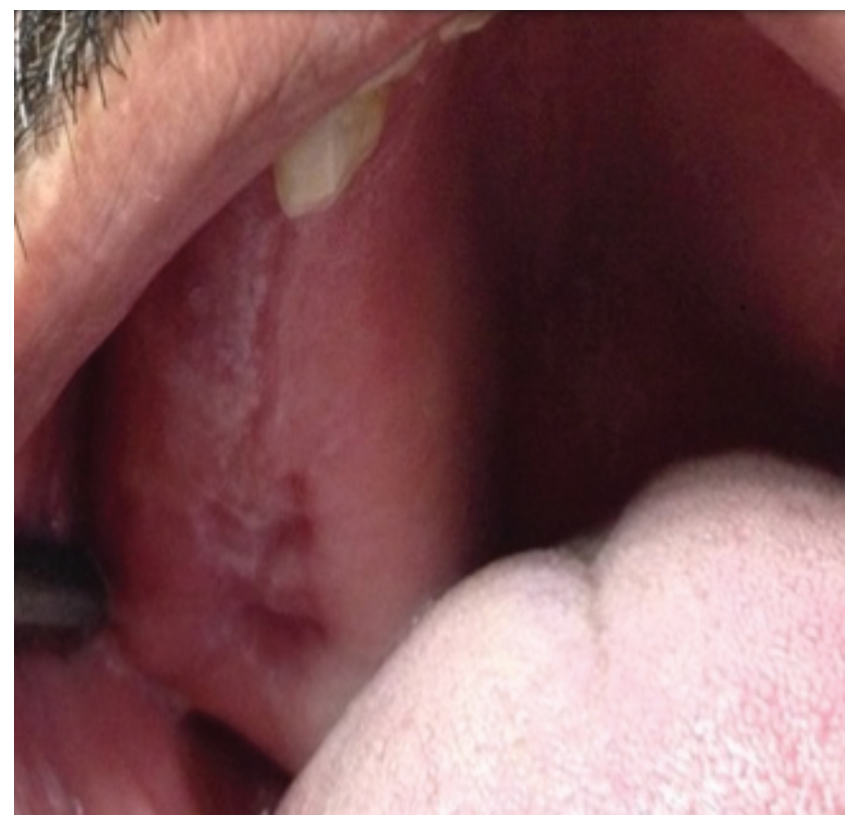

Figure 1. Intraoral photographs, swelling at the right maxillary posterior region of the patient

is noted on this radiograph with missing right maxillary molars. Teeth had been extracted a long time ago. Diffuse "ground glass" appearance was observed at the right maxillary edentulous region (Figure 2). Then, the patient was referred for the cone-beam computed tomography (CBCT) examination to determine the localization and structure of the lesions. An informed consent was obtained from patient. The CBCT image was obtained using a Promax 3D unit (Planmeca, Helsinki, Finland), operating at $90 \mathrm{kVp}, 14 \mathrm{~mA}$, with a $0.16 \mathrm{~mm}$ voxel size, exposure time of 6 seconds and a field of view of $8 \mathrm{~cm}$. A high-density area was noted extending from tuberculum molare to the right first premolar region, which leads to significant expansion of the right maxillary bone, maxillary sinus walls, intramedullary area and cortical thinning. CBCT images showed that lesion occupied significant portion of the maxillary sinus (Figure 3 ). It measured about $5 \times 3 \times 5 \mathrm{~cm}$ anteroposterior, buccopalatal, and superoinferior dimensions, respectively. Based on clinical and radiographic findings, a diagnosis of fibrous dysplasia in the patient was revealed.

Incisional biopsy of the lesion was performed under local anesthesia and was sent for histopathological examination to pathology department for definitive diagnosis. Histological examination of the bone: irregularly shaped trabecular was viewed within 
cellular fibrous stroma, composed of fibroblastic spindle cells. Planned treatment for the patient was a contour excision of the right maxillary region for prosthetic rehabilitation. He was called for control at regular intervals.

\section{Discussion}

Fibrous dysplasia is a significant lesion affecting the maxillofacial region because it can cause severe facial deformity, asymmetry (11). Craniofacial region is involved in $25 \%$ of the fibrous dysplasia cases. The maxilla and mandible are the most frequently affected bones in the craniofacial region (7). The maxilla is affected more often than the mandible and it develops more generally in the posterior region. Most of the lesions are unilateral $(2,5)$. Maxillary lesions may expand to maxillary sinus, zygoma, sphenoid bone and floor of the orbit. The form with involvement of several adjacent bones, such as sphenoid, zygoma, fronto-nasal bones and base of the skull, has been called as craniofacial fibrous dysplasia (10). Craniofacial fibrous dysplasia can cause severe

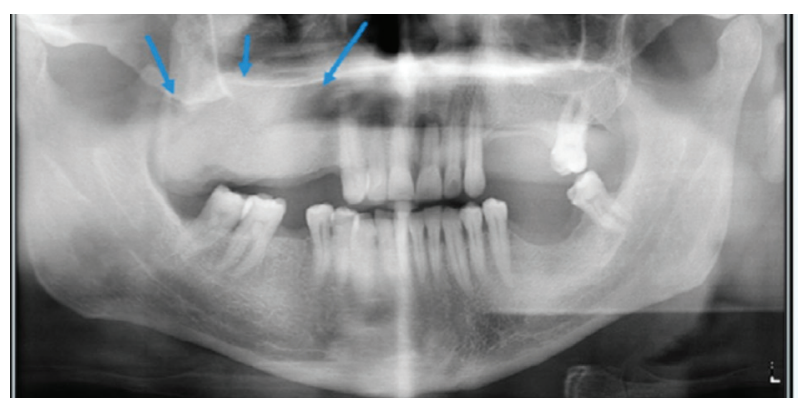

Figure 2. Panoramic radiograph, diffuse granular appearance known as a "ground glass" appearance and expansion

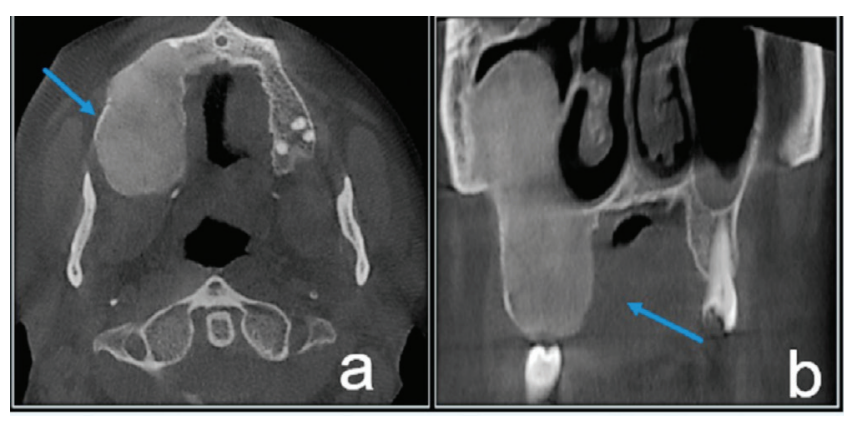

Figure 3. Cone-beam computed tomography images of the maxilla, showing a high-density area, extending from tuberculum molare to the right canine region, the outer cortical plates have been thinned a) axial, shows lesion occupied significant portion of the maxillary sinus, b) coronal planes facial deformity and asymmetry, and may lead to neurological symptoms such as hypertelorism, visual impairment and blindness by involving the orbital and periorbital bones (7). Maxillary lesions may extend into maxillary sinus and usually occur in the lateral wall, and the last section of the sinus to be involved is usually the most posterosuperior portion. Also, the peripheral border of the lesion appears as parallel thickening normal shape of the antrum (5). Obliteration of the maxillary sinus is a common finding (2). In this case, observed existing painless swelling in the right maxillary posterior region partially occupied the maxillary sinus. We diagnosed as monostatic type which affected no other bones in the maxillofacial region. The diagnosis of fibrous dysplasia is based on results of the clinical, radiological and histopathological features. The radiological appearance of fibrous dysplasia shows various appearances according to the degree of maturation and quantity of bony matrix within the lesion. In the earlier stages, the lesion may be more radiolucent and well-defined (5). As the disease progresses, it becomes mottled and more radiopaque. The distinct radiopaque patterns are described such as peau d' orange appearance, resembling the surface of an orange, granular or ground glass appearance, resembling the small fragments of a shattered windshield, wispy cotton wool like appearance, or amorphous dense pattern (5). Also, fingerprint appearance is defined as trabeculae aligned concentrically, similar to a fingerprint (12). Fibrous dysplasia commonly altered the lamina dura to the surrounding abnormal bone pattern, narrowing of periodontal ligament space is a useful diagnostic feature for this disease (12). CBCT can be useful in assessing expansion, cortical borders, and lesion's internal structure (5). There are three different image characteristics on $\mathrm{CT}$ findings. The most common appearance of fibrous dysplasia is a ground glass appearance (56\%), the others homogeneously dense pattern (23\%), and cystic variety (21\%) (8). In our case, CBCT images showed expansive mass at groundglass appearance with maxillary sinus expansion. Certain diagnosis of fibrous dysplasia is made by histopathological examination. The macroscopic appearance is in the form of a white and brown solid mass expanding the medullary cavity of the bone (7). The histopathological features show benign fibroblastic tissue, arranged in a loose, and irregular, curvilinear 
trabeculae of woven bone with little evidence of osteoblast in fibrous tissue. The bony trabeculae show an abnormal arrangement, vary in shape and some are thin and C-shaped, called as "Chinese" characters trabecular $(2,10)$. Patients with jaw involvement first may complain facial asymmetry or an enlarging deformity of the alveolar process and pain is rare (5). Although patients are usually asymptomatic, patient's age at the time of diagnosis, characteristics of pain, and process of rapid enlargement of the lesion are important points of the history. It is not accepted that biopsy or surgery is necessary for asymptomatic fibrous dysplasia, but routine follow-up of these patients should be performed (13). Radiotherapy is not recommended, because it may induce malignant transformation (8). In our case, surgical approach was carried out for prosthetic reason and the patient was called for controls with regular intervals. It must be differentiated from other diseases with a similar radiographic appearance, including central giant cell tumor, Paget disease, ossifying fibroma, giant cell reparative, granuloma, brown tumor, eosinophilic granuloma, hemangioma, and well-differentiated osteosarcoma (13). The differentiation from ossifying fibroma can be the most difficult, but ossifying fibroma is an expansive lesion with a smooth margin and has tumorlike behavior. Paget's disease influences older age groups, not unilateral like fibrous dysplasia $(5,8)$.

MacDonald-Jankowski (11) reported as $18 \%$ recurrence rate after treatment. In our case, we learned that the lesion had already developed in the same region and that a surgical procedure had been performed, do not have enough information about the size of the previous lesion. However, we think that the lesion was recur or reactive. Malignant transformation is rare, and malignancy has been described in $<1 \%$ of the cases (4). Lesions may recur or progress to more serious results such as sarcoma (11). Follow-up and recurrence are usually inter-related. Long term periodic follow-up is recommended to determine recurrence and malignant changes (10).

Fibrous dysplasia is a benign disease that has the potential to cause significant cosmetic and functional disturbance. The awareness of dentists about clinical and radiographic findings of fibrous dysplasia is important for early diagnosis. Particularly, CBCT plays an important role in the diagnosis of fibrous dysplasia.

\section{Ethics}

Informed Consent: It was taken.

Peer-review: Externally peer-reviewed.

\section{Authorship Contributions}

Medical Practices: G.A., K.G., Concept: K.G., G.A., Design: K.G., Data Collection or Processing: G.A., Analysis or Interpretation: K.G., G.A., Literature Search: G.A., Writing: G.A., K.G.

Conflict of Interest: No conflict of interest was declared by the authors.

Financial Disclosure: The authors declared that this study received no financial support.

\section{References}

1. Regezi JA, Sciubba JJ, Jordan RK. Oral Pathology. 4 th edt. Saunders Press, USA: 2003.p. 292-4.

2. Neville BW, Damm DD, Allen CM, Bouquot JE. Oral and maxillofacial pathology. 3rd ed. St. Louis: Saunders; 2009.p. 63540.

3. Park, BY, Cheon, YW, Kim, YO, Pae, NS, Lee, WJ. Prognosis for craniofacial fibrous dysplasia after incomplete resection: Age and serum alkaline phosphatase. I Int J Oral Maxillofac Surg 2010; 39: 221-6.

4. Wei YT, Jiang S, Cen Y. Fibrous dysplasia of skull. J Craniofac Surg 2010; 21: 538-42.

5. White SC, Pharoah MJ. Oral radiology. Principles and interpretation. 7 th edt. St Louis, MO: The C.V Mosby Company; 2014.p. 402-8.

6. Sontakke SA, Karjodkar FR, Umarji HR. Computed tomographic features of fibrous dysplasia of maxillofacial region. Imaging Sci Dent 2011; 41: 23-8.

7. Hanifi B, Samil KS, Yasar C, Cengiz C, Ercan A, Ramazan D. Craniofacial fibrous dysplasia. Clin Imaging 2013; 37: 1109-15.

8. Celenk P, Zengin Z, Muglali M, Celenk C. Computed tomography of cranio-facial fibrous dysplasia. European Journalof Radiology Extra 2009; 69: 85-7.

9. Jeyaraj $\mathrm{CP}$, Srinivas $\mathrm{CV}$. Craniofacial and monostotic variants of fibrous dysplasia affecting the maxillofacial region. Journal of Oral and Maxillofacial Surgery, Medicine, and Patholog, 2014; 26: 424-31.

10. Speight PM, Carlos R. Maxillofacial fibro-osseous lesions. Current Diagnostic Pathology 2006; 12: 1-10.

11. MacDonald-Jankowski D. Fibrous dysplasia: a systematic review. Dentomaxillofac Radiol 2009; 38: 196-215.

12. Petrikowski CG, Pharoah MJ, Lee L, Grace MG. Radiographic differentiation of osteogenic sarcoma, osteomyelitis, and fibrous dysplasia of the jaws. Oral Surg Oral Med Oral Pathol Oral Radiol Endod 1995; 80: 744-50.

13. Hocaoglu E, Yirgin IK, Aksoy S, Arslan G, Inci E, Cimilli T. Computed Tomography Imaging Findings of Craniofacial Fibrous Dysplasia. J Craniofac Surg 2014; 25: 1175-7. 